\title{
Plasma MiRNA-2o8b as a Biomarker for Detection of Cardiotoxicity Induced by Acute Cardiovascular Drugs Poisoning
}

\author{
Rania Hussien, Soha K. Ashry ${ }^{1}$, Sarah H. Agwa ${ }^{2}$ and Abdulhafez Selim ${ }^{3}$ \\ ${ }^{1}$ Department of Forensic Medicine and Clinical Toxicology, Faculty of Medicine, Ain Shams University, Cairo, Egypt. \\ ${ }^{2}$ Medical Research Center, Faculty of Medicine, Ain Shams University, Cairo, Egypt. \\ ${ }^{3}$ Philadelphia College of Osteopathic Medicine, Philadelphia, PA, USA.
}

\begin{abstract}
Background: Poisoning by cardiovascular drugs has harmful effects and may lead to morbidity and mortality. In cases of myocardial injury, circulating miRNA-208 levels elevate after their leakage into the bloodstream at an early stage of myocardial insult.

This study aims to assess the possible role of miRNA-208b in the early detection of myocardial injury in acute intoxicated patients with cardiovascular drugs such as digoxin, beta blockers and calcium channel blockers.

Methods: This study enrolled 40 patients with cardiovascular drug toxicity admitted to the Poison Control Center of Ain Shams University Hospitals (PCC-ASUH) from January 2016 to December 2016 in addition to 40 healthy subjects as the normal control group. Blood samples for miRNA-208b determination and troponin were collected on admission for the patients group and in the early morning for the control group. The demographic and clinical data were collected for every patient.

Results: Age and sex distribution revealed that most of studied patients were in the age group of 18 24 years accounting for $50 \%$ with female predominance $85 \%$. Beta blockers acute toxicity was the commonest cardiovascular drug toxicity $(50 \%)$ followed by digitalis $(35 \%)$ then calcium channel blockers $(15 \%)$. The box plot outlook suggested that patients with a fold change in miRNA-208b higher than 1, was at risk of having a cardiac injury (ie. Troponin positive).

Conclusion: This study concluded that miRNA-208b is a sensitive and specific biomarker in early detection of cardiac injury in patients with cardiovascular drugs poisonings for the early treatment of cardiotoxicity.
\end{abstract}

\section{Introduction}

$\mathrm{P}$ oisoning by cardiovascular drugs has harmful effects and may lead to morbidity and mortality. The most common cardiovascular drugs involved in acute toxicity are digitalis, beta blockers and calcium-channel blockers (CCBs) (Zeinvand et al., 2017).

According to records from the Poison Control Center of Ain Shams University Hospitals, Egypt, cardiovascular drugs intoxication accounts for $1.67 \%$ of the total reported poisoning cases. The most common is beta blocker $(77.8 \%)$, followed by digoxin $(18 \%)$ and calcium channel blockers toxicity $(4.2 \%)$ (PCC ASUH Annual report, 2014).

Myocardial cells have a limited capacity to regenerate so early detection of myocardial injury is very important to alleviate the extent of irreversible damage. Therefore, sensitive biomarkers which predict early signs of cardiotoxicity are needed (Schoen \& Mitchell 2010; Liu et al., 2014).

Cardiac troponin I (cTnI) is the most commonly used biomarker for diagnosing myocardial injury. However, despite that it has the ability to detect severely damaged cardiac muscle, but some myocardial insults such as ischemic damage, hypertrophy, inflammation and apoptosis may be undetected (Van Rooij et al. 2007; Aragno et al. 2008; Zhang et al. 2008; Margulies 2009).

MicroRNAs (miRNAs) are small, endogenous and noncoding RNAs involved in the regulation of gene expression. They are well established regulators of most of the biological processes by affecting protein translation. They are released from the damaged cell so their presence in the systemic circulation reflects tissue damage (Ji et al., 2009; Hruštincová et al., 2015). 
MicroRNAs (miRNAs) play a critical role in cardiac development as well as pathological processes including acute myocardial infarction, arrhythmias, hypertrophy, heart failure and atherosclerosis (Small \& Olson, 2011).

The miRNA-208; a microRNA mainly expressed in the heart, is encoded by an intron of the $\alpha$ myosin heavy chain gene. The miR-208 family includes two genes: miR-208a and miR-208b (van Rooij et al., 2007; Li et al., 2012). In cases of myocardial injury, circulating miR-208 levels elevate after their leakage into the bloodstream at an early stage of myocardial insult (Ji et al., 2009; Wang et al., 2010). MiRNA-208a rises shortly after acute cardiovascular insult but fades away in a time frame of 12 hours while the elevations in miRNA-208b persists for longer periods and serves in the follow up of cases (Koturbash et al., 2015).

This study aims to assess the possible role of miRNA-208b in the early detection of myocardial injury in acute intoxicated patients with cardiovascular drugs such as digoxin, beta blockers and calcium channel blockers admitted to the Poison Control Center of Ain Shams University Hospitals, Egypt.

\section{Materials and methods \\ Materials}

This study enrolled 40 patients with cardiovascular drug toxicity admitted to the Poison Control Center of Ain Shams University Hospitals (PCC-ASUH) from January 2016 to December 2016 in addition to 40 healthy subjects as the normal control group.

\section{Exclusion criteria}

Age below 18 years old, patients with chronic diseases, such as, cardiac or respiratory diseases, renal or liver failure are excluded from the study.

\section{Ethical Considerations}

An informed consent was obtained from the patients or their guardians before enrolment in the study. An approval of Faculty of Medicine Ain-Shams University Research Ethics Committee (FMASU REC) was obtained before starting work in the study as well as an approval from the director of the poison control center. In addition, and in order to secure confidentiality, specimens were coded and anonymously stored.

\section{Blood samples}

Blood samples were collected on admission for the patients group and in the early morning for the control group. After samples collection, blood was centrifuged at $4{ }^{\circ} \mathrm{C}$ at 3,000 rpm for $10 \mathrm{~min}$ to separate plasma. The supernatants were obtained and then put in RNA enzyme free EP tubes and stored in a $-80{ }^{\circ} \mathrm{C}$ freezer, while the remaining part of the plasma sample was used immediately to measure digoxin level.

\section{Data collection}

The demographic data including age, sex, type of the cardiovascular drug, route of administration, delay time, amount and manner of poisoning were collected in addition to clinical data which included, general examination (vital signs, skin and eye examination), neurological, cardiovascular (CVS) and respiratory systems examinations in addition to the outcome.

\section{Determination of drug levels}

Digoxin: Its level in plasma was determined using enzyme immunoassay (Emit 2000 Digoxin Assay Beckman Coulter) following the manufacturer's instructions.

Regarding beta blockers and calcium channel blockers, diagnosis was based on detailed history and meticulous clinical examination due to temporary absence of laboratory means of diagnosis.

\section{Determination of miRNA-208b}

Plasma samples:

$2 \mathrm{ml}$ of venous blood was collected from each participant in a plastic syringe containing EDTA to prevent coagulation.

Blood samples were centrifuged at $1600 \times \mathrm{g}$ for 5 minutes at $4^{\circ} \mathrm{C}$ to isolate plasma. The supernatants were transferred to Eppendorf tubes and further centrifuged at $12,000 \times \mathrm{g}$ at $4^{\circ} \mathrm{C}$ in order to get rid of the cellular components. The purified plasma samples were then transferred to new Eppendorf tubes and stored at $-80^{\circ} \mathrm{C}$ for future miRNA extraction.

\section{Total RNA extraction}

- For the real-time PCR, RNAs were extracted from plasma using mirVana PARIS kit, Cat $n^{\circ}$ AM1556, Ambion, Life Technologies, Texas, USA according to the manufacturer's protocol. $200 \mu \mathrm{l}$ of serum were mixed with an equal volume of $2 \mathrm{X}$ denaturing solution. This was followed by organic extraction using acidphenol and chloroform. The aqueous phase was mixed with 1.25 volumes of $100 \%$ ethanol at room temperature. After washing for three times, RNA was eluted using $100 \mu 195^{\circ} \mathrm{C}$ elution solution or nucleasefree water. RNA purity was assessed by its concentration and quantified by NanoDrop ND-1000 (Nanodrop, United States).

- Reverse transcription and TaqMan real-time PCR assays of microRNA:

The extracted RNA was reverse-transcribed using TaqMan microRNA RT Kit, Foster City, CA 94404, P/N 4366596 and miRNA-specific stem-loop primers (has-miR-208b P/N 4427975). Regarding the reverse transcription reaction, it was as follows: $0.075 \mu \mathrm{l}$ of $100 \mathrm{mM}$ dNTP, $0.5 \mu \mathrm{l}$ RT enzyme $(50 \mathrm{U} / \mu \mathrm{l}), 0.75 \mu \mathrm{l}$ 10X RT buffer, $0.094 \mu \mathrm{lRNAse}$ inhibitor $(20 \mathrm{U} / \mu \mathrm{l}), 2.5$ $\mu l$ eluted RNA, in addition to $2.081 \mu$ nuclease-free water. Regarding the reaction conditions, they were as follows: $16^{\circ} \mathrm{C}$ for 30 minutes, $42^{\circ} \mathrm{C}$ for 30 minutes, $85^{\circ} \mathrm{C}$ for 5 minutes, and $4^{\circ} \mathrm{C}$ till the end of the reaction.

- Real-time PCR assays of the transcribed cDNAwere performed using the TaqMan MicroRNA assays (Applied Biosystems, USA). Regarding the reaction system, it was as follows: $10.0 \mu \mathrm{l}$ of the universal mastermix II (2X), $1.0 \mu \mathrm{l} 20 \mathrm{X}$ RealTime probes, $1.0 \mu \mathrm{l}$ of cDNA, in addition to $8.0 \mu \mathrm{l}$ of nuclease-free water. Regarding the reaction conditions, they were as follows: $95^{\circ} \mathrm{C}$ for 10 minutes, followed by 40 cycles at $95^{\circ} \mathrm{C}$ for 15 seconds, and $60^{\circ} \mathrm{C}$ for 1 minute.

- The results were normalized to RNU6B expression (Applied Biosystems, Thermo Fisher Brand, Foster City, CA, USA) as the endogenous control. The detection and the analysis were performed on a 7500 Fast Real-Time PCR System (Applied Biosystems, 
USA-catalogue number 4399970). Each sample was analyzed in triplicate reactions.

- The relative expression values were calculated using the $2-\Delta \mathrm{Ct}$ method; where these values are directly related to the expression levels of miRNA-208b in each sample.

\section{Cardiac troponin I (cTnI)}

Cardiac troponin I was tested in the plasma specimens by an antigen-antibody reaction (Cardiac Troponin I Assay -cTnI-Spectrum). Qualitative detection was tested depending on the reaction of the troponin in the specimen (if present) with particles coated with anticTnI antibodies (Bodor et al., 1992).

\section{Statistical analysis}

The data were tabulated in excel sheets. MedCalc 17.6 software was used to generate the summary data and the sensitivity/specificity data. Minitab-17 software was used to generate the Boxplot graph.

\section{Results}

This study enrolled 40 patients with cardiovascular drugs intoxication and 40 healthy subjects. Age distribution revealed that most of studied patients were in the age group of 18- 24 years accounting for $50 \%$ of total cases followed by the age group 25-40 years $(37.5 \%)$. The sex distribution revealed female predominance $85 \%$ (Figure 1). The mean delay time among studied patients was $4.35 \pm 2.86$ hours. These data are presented in table 1 . Regarding the mode of poisoning, attempted suicide was recorded in all studied patients. The route of exposure was the oral route in all patients. Regarding the outcome, there were no recorded deaths in the present study.

Beta blockers toxicity was the commonest cardiovascular drug toxicity $(50 \%)$ followed by digitalis $(35 \%)$ then calcium channel blockers (15\%) (Figure 2).The mean arterial blood pressure was $84.19 \pm 14.40$ (range: $47-107$ ) and heart rate was $65.10 \pm$ 12.92 beats per minute (range: $50-105$ beats per minute).

The most common clinical manifestations among studied patients were sinus bradycardia (40\%) followed by hypotension in $16 \%$ of cases.

Digoxin level in digoxin intoxicated patients (15 cases) was measured. The level of all digoxin intoxicated patients was regarded as toxic $(>4 \mathrm{ng} / \mathrm{mL})$.

The miRNA208b data was grouped into three categories based on troponin as well as drug exposure; Not exposed; Healthy individuals who had no exposure to any cardiovascular drugs $(\mathrm{N}=10)$; Patients exposed to cardiovascular drugs but had no cardiac injury (i.e. Troponin negative) $(\mathrm{N}=8)$; and patients exposed to cardiovascular drugs and had cardiac injury (i.e. Troponin positive) $(\mathrm{N}=32)$ (Table 2). The mean of Micro RNA208b in patients exposed to cardiotoxic drugs with Troponin positive results was $2.57 \pm 1.37$ folds. Healthy patients had Micro RNA208b of $0.45 \pm$ 0.3 while exposed patients without cardiac injury have slightly higher levels at $1.0 \pm 0.0$ (Figure 3 and Table 2).

These data and the boxplot outlook suggested that patients with a fold change in miRNA 208b higher than 1 , were at the risk of having a cardiac injury (i.e. Troponin positive) (Figure 3).

We further evaluated this hypothesis (Fold change $>1$ as a marker of cardiac injury) by testing its sensitivity and specificity in the exposed population (Table 3).

Table (1): Socio-demographic characteristics of cases and controls

\begin{tabular}{|c|c|c|}
\hline & $\begin{array}{c}\text { Cases } \\
\mathbf{n = 4 0}\end{array}$ & $\begin{array}{c}\text { Controls } \\
\mathbf{n = 4 0}\end{array}$ \\
\hline Age (years) & & $19(47.5 \%)$ \\
$18-24$ & $20(50 \%)$ & $16(40 \%)$ \\
$25-40$ & $15(37.5 \%)$ & $5(12.5 \%)$ \\
$>40$ & $5(12.5 \%)$ & $10(25 \%)$ \\
Sex & $6(15 \%)$ & $30(75 \%)$ \\
Male & $34(85 \%)$ & - \\
\hline Female & $4.35 \pm 2.86$ & \\
\hline
\end{tabular}

$M=$ Mean, $S D=$ Standard Deviation, $n:$ number

Table (2): Troponin and miRNA208b in the studied groups

\begin{tabular}{|c|c|c|c|}
\hline & $\begin{array}{c}\text { Group I } \\
\mathbf{n = 4 0}\end{array}$ & $\begin{array}{c}\text { Group II } \\
\mathbf{n = 8}\end{array}$ & $\begin{array}{c}\text { Group III } \\
\mathbf{n = 3 2}\end{array}$ \\
\hline Troponin $\mathrm{ng} / \mathrm{mL}$ & Negative & Negative & Positive \\
\hline $\begin{array}{c}\text { MiR208b (folds) } \\
(\mathrm{M} \pm \mathrm{SD})\end{array}$ & $0.45 \pm 0.3$ & $1.0 \pm 0.0$ & $2.57 \pm 1.37$ \\
\hline
\end{tabular}

Group I: control group, Group II: patients with negative troponin, Group III: patients with positive troponin, M= Mean $S D=$ Standard Deviation, $n:$ number 
Table (3): Sensitivity and specificity of miRNA $208 \mathrm{~b}$ in poisoned patients

\begin{tabular}{|l|c|c|}
\hline \multicolumn{1}{|c|}{ Outcome } & Data & Notes \\
\hline True negative & 8 & \\
\hline True Positive & 41 & \\
\hline False Positive & 0 & \\
\hline False Negative & 0 & $\mathbf{9 5 \%}$ CI: $89.42 \%$ to $100.00 \%$ \\
\hline Sensitivity & $100.00 \%$ & $\mathbf{9 5 \%}$ CI: $\% 63.06 \%$ to $100.00 \%$ \\
\hline Specificity & $100.00 \%$ &
\end{tabular}

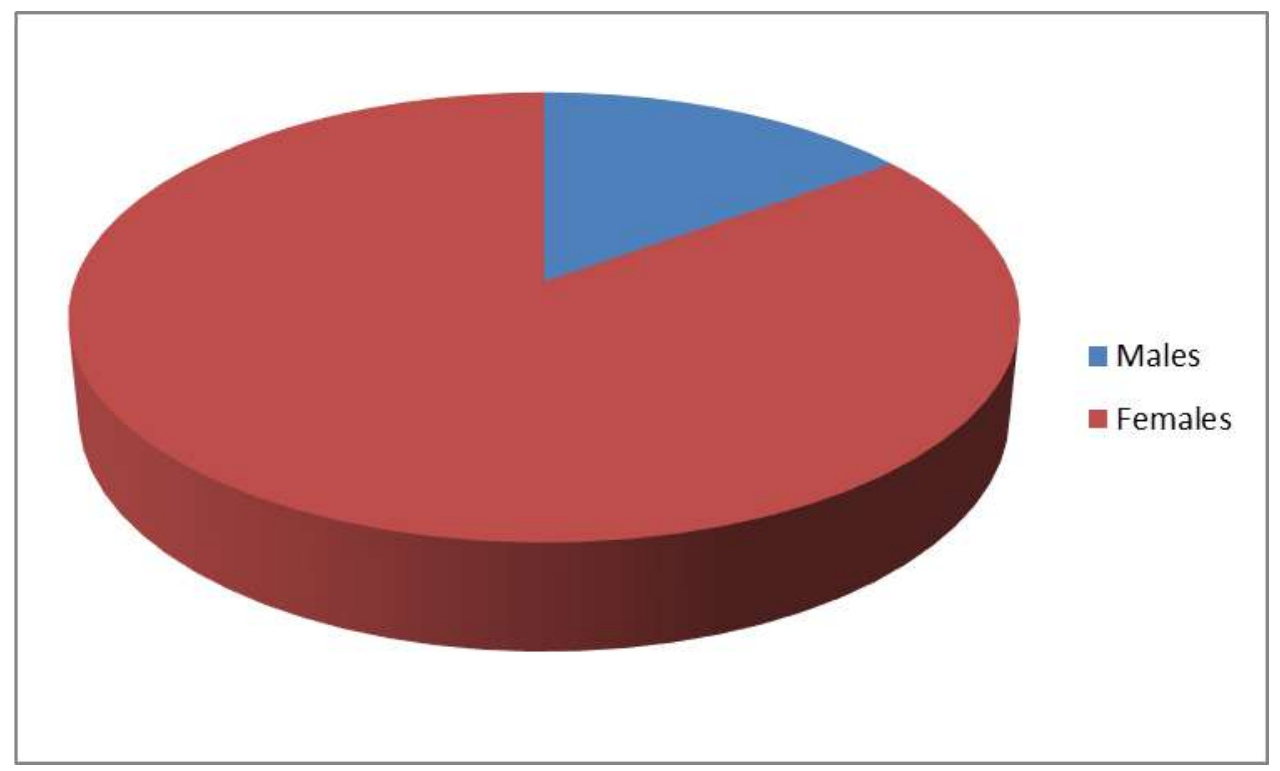

Figure (1): Pie chart showing gender distribution among poisoned cases

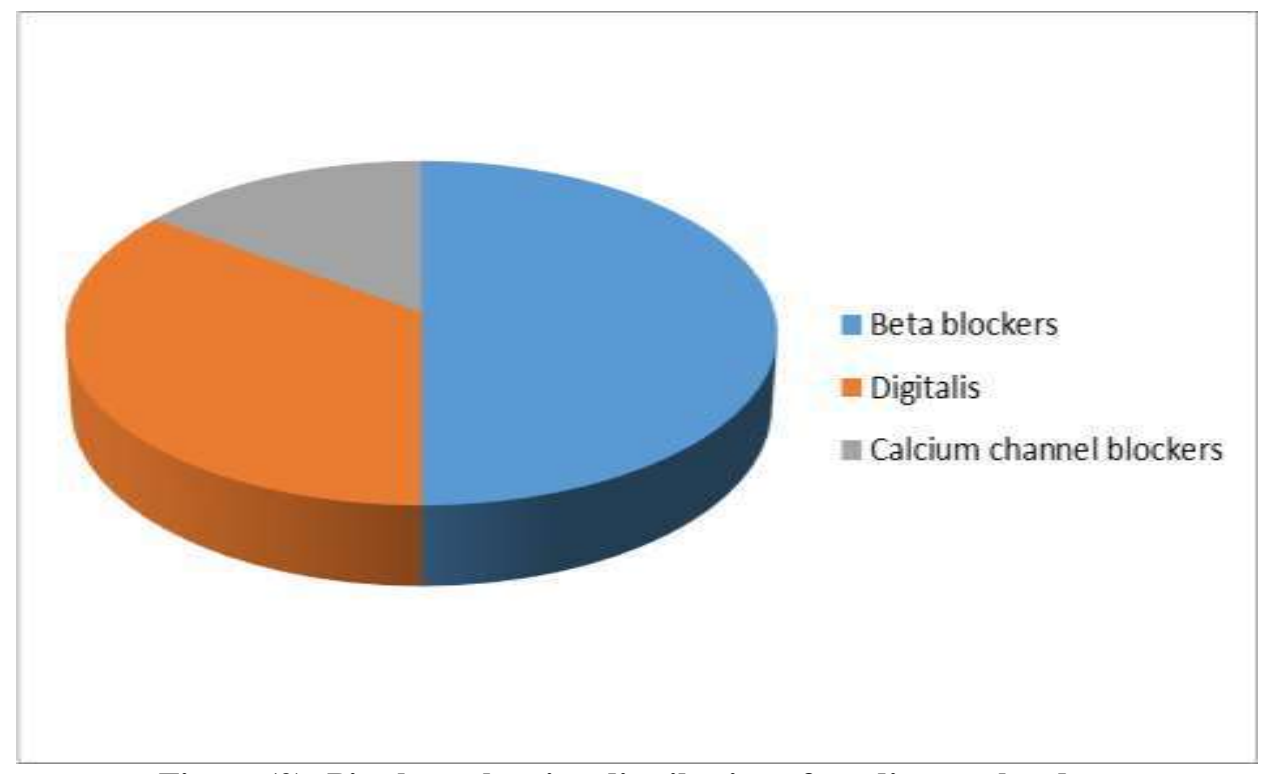

Figure (2): Pie chart showing distribution of cardiovascular drugs 


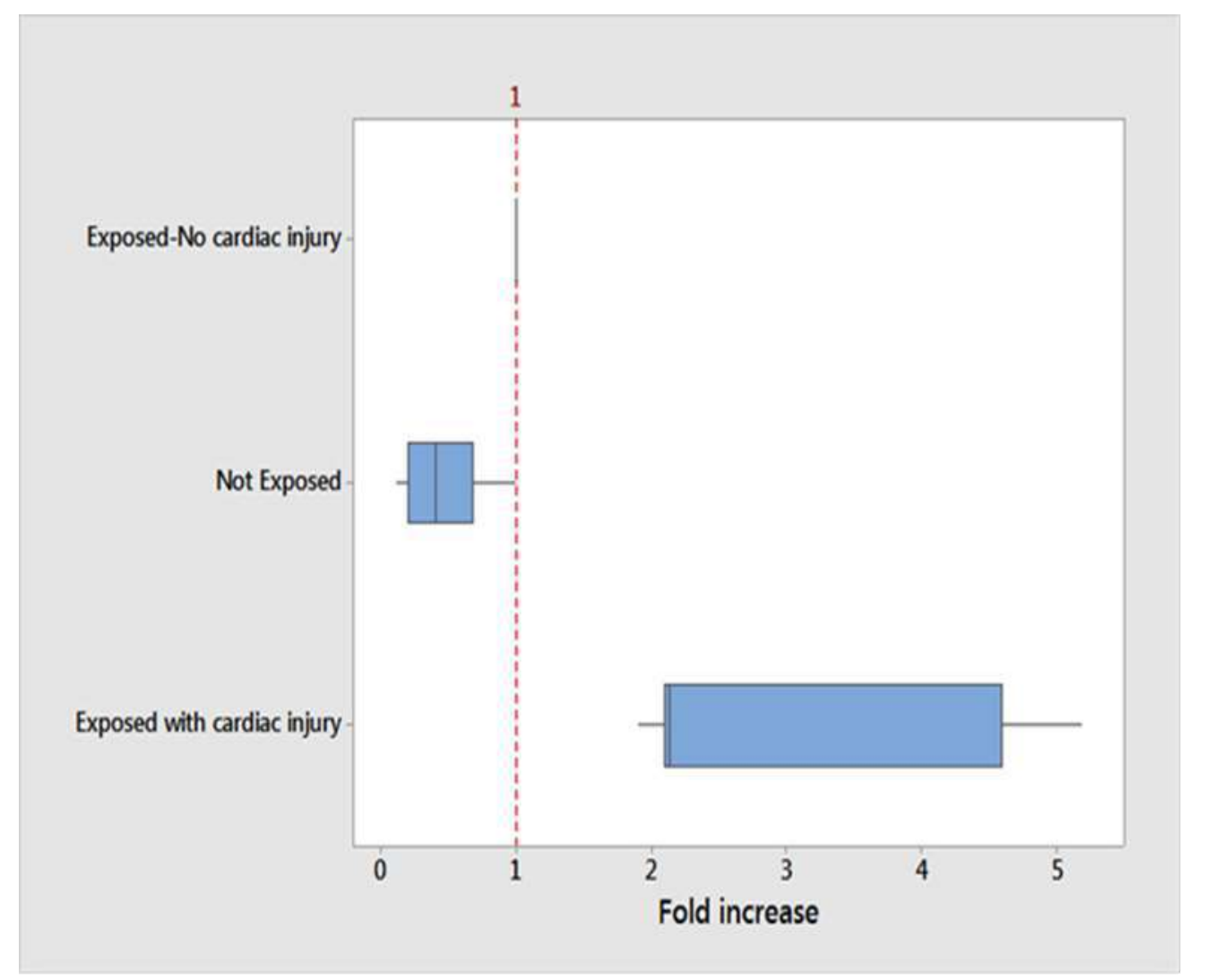

Figure (3): Box plot demonstration of the RNA fold change data. Not exposed control patients $=10$ patients, exposed without cardiac injury (i.e. Troponin negative) $=8$ patients, exposed with cardiac injury (i.e. Troponin positive) $=32$ patients.

\section{Discussion}

Cardiovascular drugs are the second most common cause of death due to poisoning after analgesics, accounting for more than $10 \%$ of all poisoning fatalities (Cole, 2017).

According to the 2016 annual report of the Poison Control Center of Ain Shams University Hospitals (PCC-ASUH), toxicity of cardiovascular drugs represented $7.8 \%$ of all poisoned cases (PCC ASUH Annual report, 2016).

The mean age of studied patients was between 18 and 63 years. The commonest age was 18-24 years. This finding is in accordance with Wasserman et al., (2005) who attributed this to various causes such as lack of social support, economic instability, unemployment and increase prevalence of depressive disorders. Ayan et al. (2016) demonstrated that cardiovascular drugs are the most common drugs causing poisoning in the elderly and this is in contrast to the current study in which most of our patients are adolescents and this is could be attributed to the availability of cardiovascular drugs due to increase rate of hypertension and cardiac diseases among the Egyptian population and dealing with it as over the counter drugs (OCD) that anyone can buy it from the pharmacy without prescription so they are attracting drugs for suicide among adolescents.

Females represented the majority of cases $(85 \%)$ while males represented only $15 \%$. This study agrees with Gross et al. (2008) who reported that suicide is the commonest cause of mortality in young girls between the ages of 15 and 19 years. Vijayakumar
(2015) explained this by high prevalence of depression in women with earlier age of its first onset

The sex distribution in this study is in contrast to Abdel Moneim et al. (2011) who reported that suicidal rates are higher in males than females and explained it by increasing the work load and stress on them in addition to males are not seeking help for psychological problems as females.

Chehil \& Kutcher (2012) attributed this to several factors such as men choose more dangerous methods in committing suicide and they are less likely to seek help for emotional problems in addition to expressing depression in manner different from women.

It is evident from this study that all patients attempted suicide. Abdelrahman et al. (2016) explained it by social and economic instabilities in Egypt especially in the last few years. Kumar et al. (2011) in India also explained it by social and economic instability of his population in addition to religious and cultural factors and availability of drugs.

The most common manifestations among studied patients were hypotension and sinus bradycardia. These manifestations are in accordance with Ayhana et al. (2015) who recorded similar findings.

The current study revealed that beta blockers toxicity was the commonest cardiovascular drug toxicity $(50 \%)$ followed by digitalis $(35 \%)$ and calcium channel blockers (15\%). This study agrees with Kalkan et al. (2010) and El Masry \& Tawfik (2013). 
Cole (2017) reported that the three classes of CVS drugs; Digoxin, beta blockers and calcium channel blockers account for the majority of cardiovascular drugs poisonings fatalities.

Kalkan et al. (2010) explained increase the frequency of beta blockers toxicity by widespread prescription of these medications for hypertension and angina.

Increased frequency of self-poisoning with beta blockers among adolescent in this study could be attributed to their easy availability due to widespread prescription of these medications for treatment of hypertension among the Egyptian population in addition to selling it without prescription so they are considered as attracting drugs for suicide among adolescents.

In contrast to our study, Brusin et al. (2016) in Russia found that calcium channel blockers toxicity was the commonest cardiovascular drug toxicity among his studied patients and explained it by widespread use of these drugs in his country for treatment of hypertension. Ayhan et al. (2015) in Turkey reported that digitalis toxicity is the most common cardiovascular drug toxicity.

Cardiac troponin I was positive in $80 \%$ of the studied patients. This study agrees with several studies (Jensen et al., 2007; O’Brien, 2008; Giannitsis \& Katus, 2009 and Manini et al., 2015) which reported the usefulness of troponin I in diagnosis of cardiac injury induced by drugs with different pathologies such as from acute coronary syndrome, left ventricular hypertrophy, heart failure and pulmonary embolism.

On the other hand, Abbas et al. (2005) reported that cardiac troponin $\mathrm{I}$ is occasionally increased in severe renal disease, even in the absence of an acute coronary syndrome which means that it is not a specific biomarker for cardiac injury.

In the present study, the box plot outlook revealed that patients with a fold change in miRNA 208b higher than 1, are at the risk for cardiac injury. Accordingly and based on this data, sensitivity and specificity data were generated based on $>1$ fold criteria and they revealed that miRNA-208b is very reliable based on its high sensitivity and specificity profile in the diagnosis of cardiac insult. Wang et al. (2010) demonstrated that miRNA-208 is a cardiospecific biomarker which is only detectable following cardiac injury and it is not affected by the non-cardiac tissue injury with the highest sensitivity and specificity for diagnosis of cardiac injury during the early stage. In addition, Ji et al. (2009) reported that plasma miRNA208 could be superior to cardiac troponin for detection of cardiac injury in patients with renal dysfunction. These findings are in accordance with the findings of the present study. Moreover, the present study focused on measuring serum miRNA-208b whose concentrations are known to be detectable for longer periods in the blood stream (Koturbash et al., 2015) to be used in the diagnosis of cardiac toxicity.

\section{Conclusion}

This study concluded that miRNA-208b is a sensitive and specific biomarker in the early detection of cardiac injury among patients with acute cardiovascular drugs poisonings. This new means of diagnosis will aid in the early management of cardiac intoxicated patients, in improving patients' outcome which will in return lead to decreasing the waste in hospital resources.

\section{Conflict of interest}

The authors declare that they have no conflict of interest.

\section{References}

Abbas, N.A., John, R.I., Webb, M.C., Kempson, M.E., Potter, A.N., Price, C.P., et al.2005. Cardiac troponins and renal function in nondialysis patients with chronic kidney disease. Clin. Chem. 51,2059-66.

Abdel Moneim, W.M., Yassa, H.A., George, S.M., 2011. Suicide rate: Trends and implications in Upper Egypt. Egyptian Journal of Forensic Science.1,48-52.

Abdelrahman, A.A., Saad, A.A., Sabry, N.A., Farid, S.F., 2016. Perceptions of Egyptian physicians about drug shortage during political disturbances: Survey in Greater Cairo. Bulletin of Faculty of Pharmacy, Cairo University.54, 191-196.

Aragno, M., Mastrocola, R., Alloatti, G., Vercellinatto, I., Bardini, P., Geuna, S., Catalano, M.G., Danni, O., Boccuzzi, G. 2008. Oxidative stress triggers cardiac fibrosis in the heart of diabetic rats. Endocrinology.149, 380-88.

Ayan, M., Pothineni, N.V., Siraj, A., and Mehta, J.L. 2016. Cardiac drug therapy-considerations in the elderly. J. Geriatr. Cardiol.13(12), 992997.

Ayhana, H., Ozucelik, D.N., Dogan, H., Erdogan, M.O., Yigit, Y. 2015. Suicidal Cardiovascular Drug Intoxication in Emergency Department. HSP. 2(3), 329-333.

Bodor, S.G. et al. 1992. Development of monoclonal antibody for an assay of cardiac troponin I and preliminary results in suspected cases of myocardial infarction. Clin. Chem. 38:2203

Brusin, K.M., Sentsov, V.G., Krayeva, Y.V., Kondrashov, D.L., Lund, C., Hovda, K.E. 2016. Poisonings by Cardiovascular Drugs in Yekaterinburg, Russia. Asia Pacific Journal Of Medical Toxicology.5 (1), 3-10.

Chehil, S. and Kutcher, S. 2012. Suicide risk management: A manual for health professionals. 2nd Edition, Sussex: John Wiley \& Sons, Ltd. P, 56-88.

Cole, J.B. 2017. Cardiovascular Drugs. In: Rosen's Emergency Medicine - Concepts and Clinical Practice E-Book. Walls, R., Hockberger, R., Gausche-Hill, M. (Eds.). Chapter 147. P, 1876-1889.

El Masry, M.K. and Tawfik, H.M. 2013. 2011 Annual Report of the Poison Control Centre of Ain Shams University Hospital, Cairo, Egypt. Ain Shams Journal of Forensic Medicine and Clinical Toxicology. 20, 10-17. 
Giannitsis, E. and Katus, H.A., 2009. Troponins and highsensitivity troponins as markers of necrosis in CAD and heart failure. Herz. 34, 600-606.

Gross, V.A., Weiss, M.G., Ring, M., Hepp, U., Bopp, M., Gutzwiller, F., Rössler, W. 2008. Methods of suicide: international suicide patterns derived from the WHO mortality database Bulletin of the World Health Organization. 86 (9), 726-732.

Hruštincová, A., Votavová, H., Dostálová Merkerová, M. 2015. Circulating MicroRNAs: Methodological Aspects in Detection of These Biomarkers. Folia Bio (Praha). 61, 203-218.

Jensen, J.K., Atar, D., Mickley, H. 2007. Mechanism of troponin elevations in patients with acute ischemic stroke. Am J Cardiol. 15, 867-870.

Ji, X., Takahashi, R., Hiura, Y., Hirokawa, G., Fukushima, Y., Iwai, N. 2009. Plasma miR208 as a biomarker of myocardial injury. Clinical Chemistry. 55(11), 1944-1949.

Kalkan, S., Hocaoglu, N., Oransay, K., Unverir, P., Tuncok, Y 2010.. Cardiovascular medication exposures and poisonings in Izmir, Turkey: A 14-year experience. Human and Experimental Toxicology. 30(5), 347-353.

Koturbash, I., Tolleson W.I., Guo, L., Yu D., Chen, S., Hong, H., Mattes, W., Ning, B. 2015.

MicroRNAs as Pharmacogenomics

Biomarkers for Drug Efficacy and Drug

Safety Assessment Biomark. Med. 9(11), 1153-1176

Kumar, S., Pathak, A., Mangal, H.M. 2011. Trends of Fatal Poisoning In Saurashtra Region of Gujarat (A Prospective Study). J. Indian Acad. Forensic Med. 33(3), 197-199.

Li, C., Pei, F., Zhu, X., Duan, D.D., Zenga, C. 2012. Circulating microRNAs as novel and sensitive biomarkers of acute myocardial Infarction. Clin. Biochem. 45(0), 727-732.

Liu, L., Aguirre, S.A., Evering, W.E., Hirakawa, B.P., May, J.R., Palacio, K., Wang, J., Zhang, Y. and Stevens, G.J. 2014. miR-208a as a biomarker of isoproterenol-induced cardiac injury in Sod2+/- and C57BL/6J wild-type mice. Toxicol Pathol. 42(7), 1117-29.

Manini, A.F., Stimmel, B., Hoffman, R.S., Vlahov, D. 2015. Utility of Cardiac Troponin to Predict
Drug Overdose Mortality. Cardiovasc. Toxicol. 16, 355-360.

Margulies, K.B. 2009. MicroRNAs as novel myocardial biomarkers. Clin Chem 55, 189799.

O'Brien, P.J. 2008. Cardiac troponin is the most effective translational safety biomarker for myocardial injury in cardiotoxicity. Toxicology. 245, 206-218.

PCC (Poison Control Center) Ain Shams University Hospitals annual report 2014.

PCC (Poison Control Center) Ain Shams University Hospitals annual report 2016.

Schoen, F.J. and Mitchell, R.N. 2010. The heart. In: Robbins and Cotra Pathologic Basis of Disease. V. Kumar, V., Abbas, A. K., Fausto, N., Aster, C. (Eds.). $8^{\text {th }}$ Edition. Elsevier Inc., Philadelphia, PA. p, 529-87.

Small, E.M. and Olson, E.N. 2011. Pervasive roles of microRNAs in cardiovascular biology. Nature. 469(7330), 336-342.

Van Rooij, E., Sutherland, L.B., Qi, X., Richardson, J.A., Hill, J., Olson, E.N. 2007. Control of stress dependent cardiac growth and gene expression by a microRNA. Science. 316, 575-79.

Vijayakumar, L. 2015. Suicide in women. Indian J. Psychiatry. 57(2), S233-S238.

Wang, G.K., Zhu, J.Q., Zhang, J.T., Li, Q., Li, Y., He, J., Qin, Y.W., Jing, Q. 2010. Circulating microRNA: a novel potential biomarker for early diagnosis of acute myocardial infarction in humans. European Heart journal. 31(6), 659-666.

Wasserman, D., Cheng, Q., Jiang, G.X. 2005. Global suicide rates among young people aged 15-19. World Psychiatry. 4(2), 114-120.

Zeinvand, M., Hoseini, T., Rahmani, A. 2017. A Clinico Epidemiological Study on Poisonings due to Cardiovascular Drugs in Ahvaz, Iran. Asia Pacific Journal OF Medical Toxicology, 6, 25-28.

Zhang, J., Knapton, A., Lipshultz, S.E., Weaver, J.L., Herman, E.H. 2008. Isoproterenol-induced cardiotoxicity in Sprague-Dawley rats: Correlation of reversible and irreversible myocardial injury with release of cardiac troponin $\mathrm{T}$ and roles of iNOS in myocardial injury. Toxicol Pathol. 36, 277-88. 


\section{الملخص العربي}

الريبونيوكلياز الجزئى ^ • ب ب بالبلازما كمؤشر حيوى للكشف عن السمية القلبية الناتجة عن التسمم الحاد بعقاقير القلب والأوعية الدموية

رانيا حسين و سهى خالد عشري' و سارة حسن عجوة׳ و عبدالحافظ سليم

خلفية: التسمم بعقاقير القلب والأوعية الدموية له آثار ضارة قد تؤدي إلى المرض المزمن والوفاة. فى حالة إصابة عضلة القلب،

ترتفع نسبة مادة الريبونيوكلياز الجزئية ^ • ب ب بالدورة الدموية بعد تسربها لجرى الدم في مرحلة مبكرة من تأذى عضلة القلب.

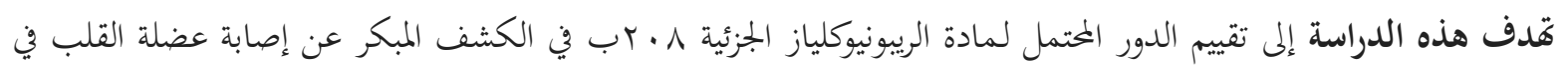

المرضى المصابين بالتسمم الحاد بالعقاقير المؤثرة على القلب مثل عقار الديجوكسين وحاصرات مستقبلات البيتا وحاصرات قنوات البهات

الكالسيوم.

الطريقة: أجريت هذه الدراسة على •ـ مريضا يعانون من التسمم الحاد بالأدوية المؤثرة على القلب والذين تم إستقباهم

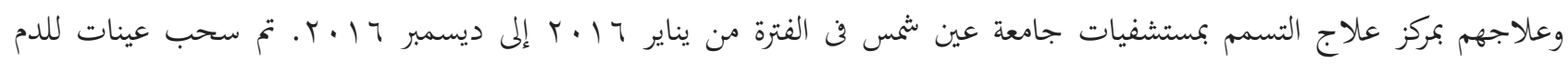
وحفظها لحين تحليل نسبة مادةالريبونيوكلياز الجزئية م • ب وب والتروبونين عند الدخول بالنسبة لمجموعة المرضى؛ وفن الصباح الباكر بالنسبة

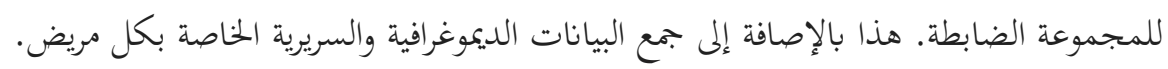

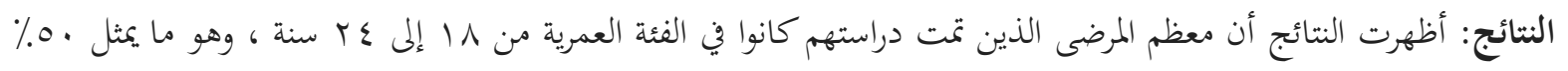
مع غلبة نسبة الإناث حيث مثلن ه1\% من إجمالى عدد الحالات. مثلت نسبة المرضى المصابين بالتسمم الحاد بحاصرات مستقبلات البيتا

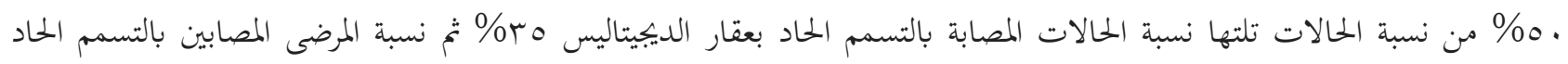

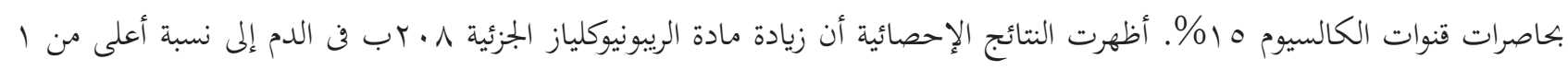

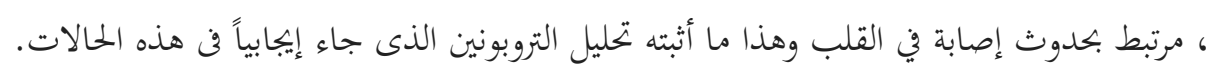

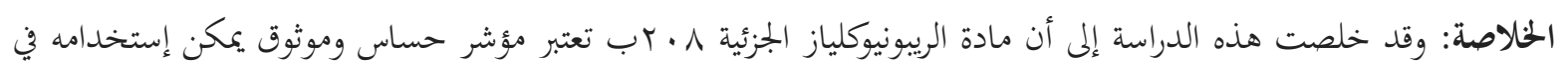

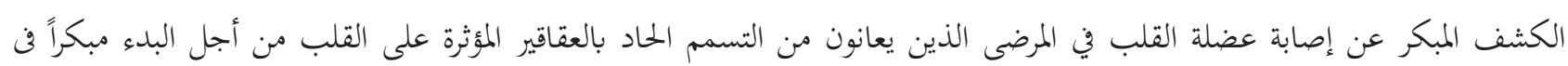

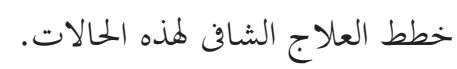

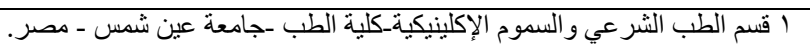
r r r r r الأبحاث الطبي _كلية الطب -جامعة عين شمس - مصر. r r كلية النقويم الطبي - فلاديلفيا - الو لايات المتحدة الأمريكية 